\title{
Recent Advances in the Role of Microorganisms in Cancer Incidence: Mechanisms and Health Precautions
}

\author{
Esam Bashir Yahya ${ }^{1, *(1)}$, Muhanad Abdullah Abdulsamad ${ }^{2}$, Abdulmutalib Alabeed Allaq $^{3}$
}

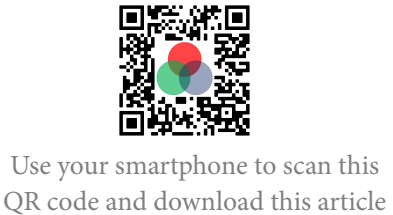

${ }^{1}$ School of Industrial Technology, Universiti Sains Malaysia, Penang, Malaysia

${ }^{2}$ Faculty of Science, Sabratha University, Sabratha, Libya

${ }^{3}$ Faculty of applied science, Universiti Teknologi MARA, Shah Alam, Malaysia

\section{Correspondence}

Esam Bashir Yahya, School of Industrial Technology, Universiti Sains Malaysia, Penang, Malaysia

Email: essam912013@gmail.com

\section{History}

- Received: Aug 29, 2021

- Accepted: Sep 13, 2021

- Published: Sep 29, 2021

DOI : 10.15419/bmrat.v8i9.691

\section{Check for updates}

\section{Copyright}

(- Biomedpress. This is an openaccess article distributed under the terms of the Creative Commons Attribution 4.0 International license.

\begin{abstract}
Humans harbor various microorganisms, some of which reside naturally in the body, and some of which are transferred from elsewhere. Many of these microbes are considered to be normal flora that do not cause disease, provided that they occur only in their normal anatomical site in the body. The development of malignant lesions requires a long incubation time, even after direct exposure to known carcinogens. Multistep tumorigenesis is required to transform a normal cell into a cancerous one. The role of different microbes in tumorigenesis has expanded to include their potential capacity to form and modulate several cancer hallmarks, including the alteration of the immune response, tumor-promoting inflammation, angiogenesis, tumor growth and proliferation, and pro-carcinogenic metabolite production. Furthermore, microbes may damage the host DNA and induce genomic instability. This review provides a basic overview of the process of tumorigenesis and the role of different microorganisms in cancer accuracy. Then this study discusses the different mechanisms of tumor induction by viruses, bacteria, protozoa, and fungi. Finally, it highlights the necessary health precautions that need to be taken to prevent the development of cancers.

Key words: cancer, carcinogenesis, incidence, health precaution, microorganisms
\end{abstract}

\section{INTRODUCTION}

Cancer is one of the most common diseases worldwide. It is the result of the uncontrolled growth of abnormal cells due to genetic mutations. Cancer develops when normal cells lose control of their proliferation. They keep growing and dividing rather than dying, and this forms a new, abnormal mass of tissue called a tumor ${ }^{1}$. Despite the advances made in oncological diagnoses, management, and therapy, there has been a steady increase in the number of cancer patients globally ${ }^{2}$. Many studies estimate that roughly $20-25 \%$ of all human malignancies worldwide are related to microbial infections ${ }^{3,4}$. The role of different microbes in tumorigenesis has expanded to include their potential capacity to form and modulate several cancer hallmarks, including the alteration of the immune response $\mathbf{5}^{\mathbf{5}}$, tumor-promoting inflammation ${ }^{6,7}$, angiogenesis ${ }^{8}$, tumor growth and proliferation $^{9}$, and pro-carcinogenic metabolite production $^{10}$. Furthermore, microbes may damage the host DNA and induce genomic instability ${ }^{\mathbf{1 1}, 12}$. Various oncogenic mechanisms have been suggested for viruses, bacteria, protozoa, and fungi.

Recently, a number of review articles have discussed the mechanism of tumorigenesis for single microbes, including viruses ${ }^{13}$, bacteria ${ }^{14}$, protozoa $^{15}$, and fungi ${ }^{\mathbf{1 6}}$. Other reviews have comprehensively covered the role of microbes and their relation to can$\operatorname{cer}^{17,18}$ and their effect on the human immune system ${ }^{19}$. To the best of our knowledge, no comprehensive review has yet been published that discusses the role of all microorganisms in the incidence of cancer. The current review provides a straightforward overview of oncogenic microorganisms and the process of tumorigenesis. It explores different carcinogenic microorganisms and their mechanisms in cancer induction, and it also highlights the necessary health precautions that can be undertaken to prevent the development of cancer.

\section{MECHANISMS OF MICROBIAL CARCINOGENESIS}

Microbial infections have recently been recognized as one of the top causes of many types of cancer, especially in undeveloped and developing counties due to poverty and unhygienic environments ${ }^{20}$. International cancer research agencies have classified infections due to eleven pathogenic species as Group 1 carcinogens. These include the hepatitis $\mathrm{B}$ virus, hepatitis $\mathrm{C}$ virus, Helicobacter pylori, Clonorchis sinensis, Opisthorchis viverrini, Schistosoma haematobium, human papillomavirus, human T-cell lymphotropic virus, human immunodeficiency virus, Epstein-Barr 
virus, and human herpesvirus ${ }^{21,22}$. Most of the emphasis has been on viruses due to their direct influence on human genes ${ }^{23}$ and bacteria, which causes chronic inflammation leading to cancer ${ }^{24}$. Although fungi and parasitic protozoa have largely been overlooked, they are now being investigated as important factors in microbial carcinogenesis ${ }^{25,26}$.

\section{Carcinogenic viruses}

The history of tumor virology began in 1911 with the discovery of a filterable agent capable of inducing sarcomas in chickens ${ }^{27}$. Later on, this filterable agent was shown to be a retrovirus that proved able to transduce a gene, $v$-src, and induce tumors. The beginning of human tumor virology came in the 1960s following the discovery of the Epstein-Barr virus (EBV) ${ }^{28}$ that was first observed using electron microscopy in cells cultured from Burkitt's lymphoma ${ }^{29}$.

International cancer research agencies have classified seven viral pathogens as highly carcinogenic agents. These agencies have also estimated that 1 in 10 cancers is caused by viruses ${ }^{30,31}$. Each year, a total of 640,000 cancers are caused by human papillomaviruses (HPVs) alone ${ }^{32}$. The etiological role of HPV in cervical carcinoma was first proposed in the 1970 s by zur Hausen. Recent research indicates that HPV accounts for more than half of infection-linked cancers in females ${ }^{33,34}$. von Knebel Doeberitz et al. ${ }^{35}$ reported that HPV infects human epithelial cells, integrates into their DNA, and produces oncoproteins including E6 and E7. The oncoproteins are able to disrupt the natural tumor suppressor pathways and inhibit apoptosis. This permits the proliferation of cervical carcinoma cells. HPVs have also been determined to be the main cause of other human cancers including skin cancers in immunosuppressed patients ${ }^{36}$, head and neck tumors ${ }^{37}$, and other anogenital cancers ${ }^{38}$. Rusan et al. $(2015)^{39}$ described 3 main pathways for HPV integration and tumorigenesis: an increase in oncogene expression, a loss of function of the tumor suppressor genes, and interand intra-chromosomal rearrangements. Langsfeld et al. (2016) ${ }^{40}$ studied the life cycle of HPV and cervical cancer induction and reported that when the viral genomes migrate to the nucleus of the cervical epithelial cells (maintained at $\sim 100$ copies/cell), the virus is continuously amplified in the daughter cells. The expression of oncoproteins (E6 and E7) is increased, leading to a significant enhancement of the cells' proliferation and the accumulation of cellular mutations ${ }^{41}$. This leads to a loss of cellular differentiation and the cancerous cells invading the dermal layer and neighboring tissues. Figure 1 illustrates the life cycle of HPV during cancer formation as well as the epithelial architecture before and after the virally induced cancer.

Human herpes viruses are a family of oncogenic viruses. This family includes human herpesvirus-8, the main causal agent of Kaposi's sarcoma and human herpesvirus-6, which has been found to be significantly related to the etiologies of brain cancers and lymphomas ${ }^{43,44}$. Although the tumorigenesis mechanisms of these viruses have not yet been firmly established, many studies have suggested that several attributes of these viruses that can promote tumorigenesis ${ }^{45,46}$. Choi et al. (2020) ${ }^{\mathbf{4 6}}$ investigated the mechanism of tumorigenesis in human herpesvirus and revealed that upon viral infection, the virus increases the metabolites of non-essential amino acids. The $\mathrm{K} 1$ oncoprotein of the viruses interacts with and activates the Pyrroline-5-carboxylate reductase enzyme, leading to an increase in the intracellular concentrations of proline. Consequently, the interaction of the viruses' $\mathrm{K} 1$ oncoprotein and the reductase enzyme promotes tumorigenesis and tumor cell growth. Kang et al. (2017) ${ }^{47}$ reviewed Kaposi's sarcoma-associated herpesvirus and reported its ability to cause various tumors in humans. The tumors begin with the infection of the endothelial and B- cells by Kaposi's sarcoma-associated herpesvirus, leading to the formation of 1 of 3 malignancies, including Kaposi's sarcoma and 2 B-cell lymphomas. In the early stages of the endothelial tumor infection (Kaposi's sarcoma), predominant inflammation and aberrant neoangiogenesis have been reported. However, in the later stages due to the proliferation of infected spindle cells, a serious modification of newly formed endothelial cell has been observed, although the origin of the endothelial cells remains elusive ${ }^{48}$. The increased rate of proliferation of the modified endothelial cells, in addition to its angiogenic and migratory capacities, is the primary mechanism of Kaposi's sarcoma oncogenesis as posited in the previous research.

The Hepatitis $C$ virus belongs to a group of enveloped RNA viruses from the flavivirus family. It is the causative agent for both acute and chronic hepatitis ${ }^{49}$. In contrast, hepatitis B virus is a DNA virus from a different family, hepadnaviridae ${ }^{\mathbf{5 0}}$. However, the diseases that result from both hepatitis C and B share many similarities. El-Serag et al. $(2012)^{51}$ estimated that roughly $80 \%$ of hepatocellular carcinomas worldwide are associated with chronic infections of hepatitis B virus and/or hepatitis C virus. Different studies have found there to be a relationship between intrahepatic cholangiocarcinoma and the hep- 


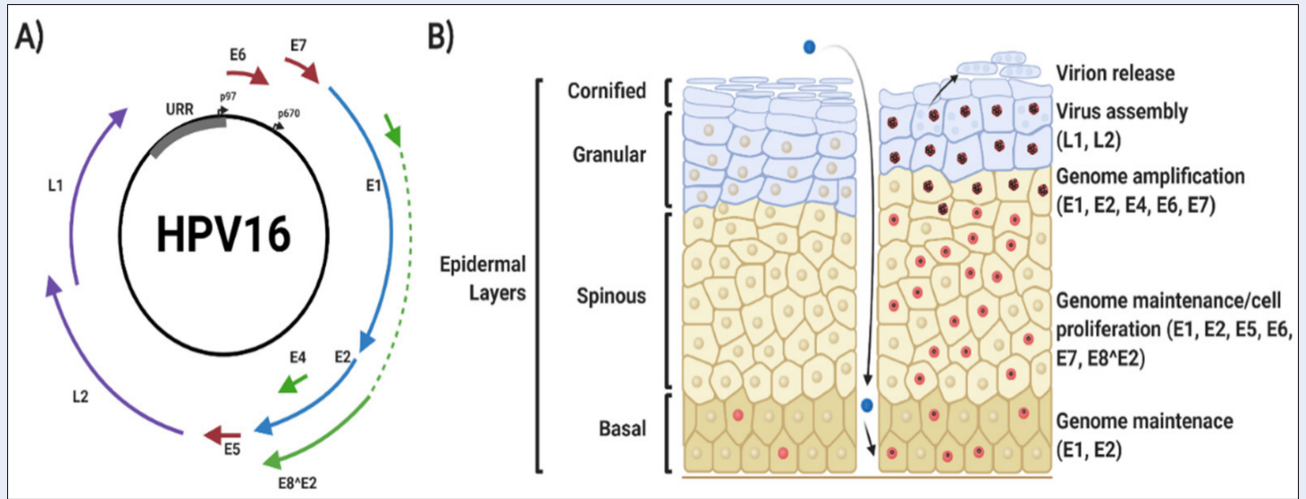

Figure 1: Life cycle and cancer formation of Human papillomavirus. A) The relative position of viral genes, B) schematic of epithelial architecture before and after viral induced cancer. Adapted from Morgan \& Macdonald (2020) $^{42}$. https://doi.org/10.6084/m9.figshare.16702444.v1

atitis $\mathrm{C}$ or B viruses ${ }^{\mathbf{5 2}}$. Worldwide, it has been estimated that 2 billion people are infected with hepatitis $B$ virus, and that 1.2 million deaths every year are attributed to subsequent cirrhosis, hepatocellular carcinomas (HCCs), and hepatitis ${ }^{53}$. A meta-analysis performed in China that included 39 studies from 1954 to 2010 revealed that more than $70 \%$ of hepatocellular carcinomas were associated with hepatitis B virus infection, $5 \%$ with hepatitis $\mathrm{C}$ virus infection, and $6 \%$ with hepatitis $\mathrm{B}$ and $\mathrm{C}$ co-infection, although up to $19 \%$ of hepatocellular carcinoma cases showed no relationship with hepatitis B or $\mathrm{C}^{\mathbf{5 4}}$. The majority of patients infected with both viruses developed a chronic hepatitis infection followed by inflammation-induced lesions. This triggered the secretion of various cytokines in the liver ${ }^{55,56}$. As a result of these events, cirrhosis and hepatocellular carcinoma were likely to develop. Vescovo et al. (2016) ${ }^{57}$ studied the molecular mechanisms of human hepatitis $\mathrm{C}$ virus and reported that HCC is a multistep process that leads to malignant transformation. This begins with the viral infection, chronic inflammation, and induction of lesions, followed by fat accumulation (steatohepatitis) in addition to progressive fibrosis. This process occurs over a period of 20 to 40 years, and $10-20 \%$ of patients went on to develop cirrhosis, whereas 1 $-5 \%$ developed typical HCC. The malignant transformation of the liver cells (hepatocytes) occurs due to the increased liver cell turnover resulting from chronic liver injury and subsequent regeneration ${ }^{\mathbf{5 7}}$. The chronicity of these events, in addition to the oxidative stress, promotes and directly up-regulates the mitogenic pathways that block apoptosis, enhancing cell proliferation and inducing reactive oxygen species
(ROS). Hepatitis viruses also triggers the immune response to produce several cytokines such as LT $\alpha$ and LT $\beta$, which have been reported to play a vital role in HCC development ${ }^{58}$. The prolonged release of ROS is considered to be the main source of genetic mutations and tumorigenesis. Figure 2 presents the role and mechanisms of the hepatitis $\mathrm{C}$ virus from infection to HCC.

Epstein-Barr virus is a herpesvirus that has a large genome consisting of double-stranded DNA. This encodes all of the enzymes involved in the replication of its DNA and in nucleotide biosynthesis ${ }^{\mathbf{6 0}}$. It has been linked to a number of malignancies, such as Hodgkin's disease ${ }^{61}$, B- and T-cell lymphomas ${ }^{62}$, leiomyosarcomas ${ }^{63}$, post-transplant lymphoproliferative disease ${ }^{64}$, and nasopharyngeal carcinomas ${ }^{65}$. Among all of these cancers, the frequency of Burkitt's lymphoma, leiomyosarcomas and posttransplant lymphoproliferative disease have dramatically increased in the past few years especially in patients who suffer from immunodeficiency, revealing the role of immunosurveillance in the prevention and suppression of malignant transformation ${ }^{\mathbf{6 6}}$. Naseem et al. (2018) ${ }^{67}$ reported multiple factors associated with EBV that contribute to tumorigenesis, including inflammatory changes induced by the viral attack, the hypermethylation of the tumor suppressor genes, the induction of changes in the cell cycle pathways, and host immune evasion by the virus.

Human immunodeficiency virus (HIV) is a carcinogenic virus derived from the lentivirus family. It is responsible for acquired immunodeficiency syndrome (AIDS) and it has resulted in more than 20 million deaths worldwide ${ }^{\mathbf{6 8}}$. Individuals with HIV have been reported to have a significantly higher incidence 


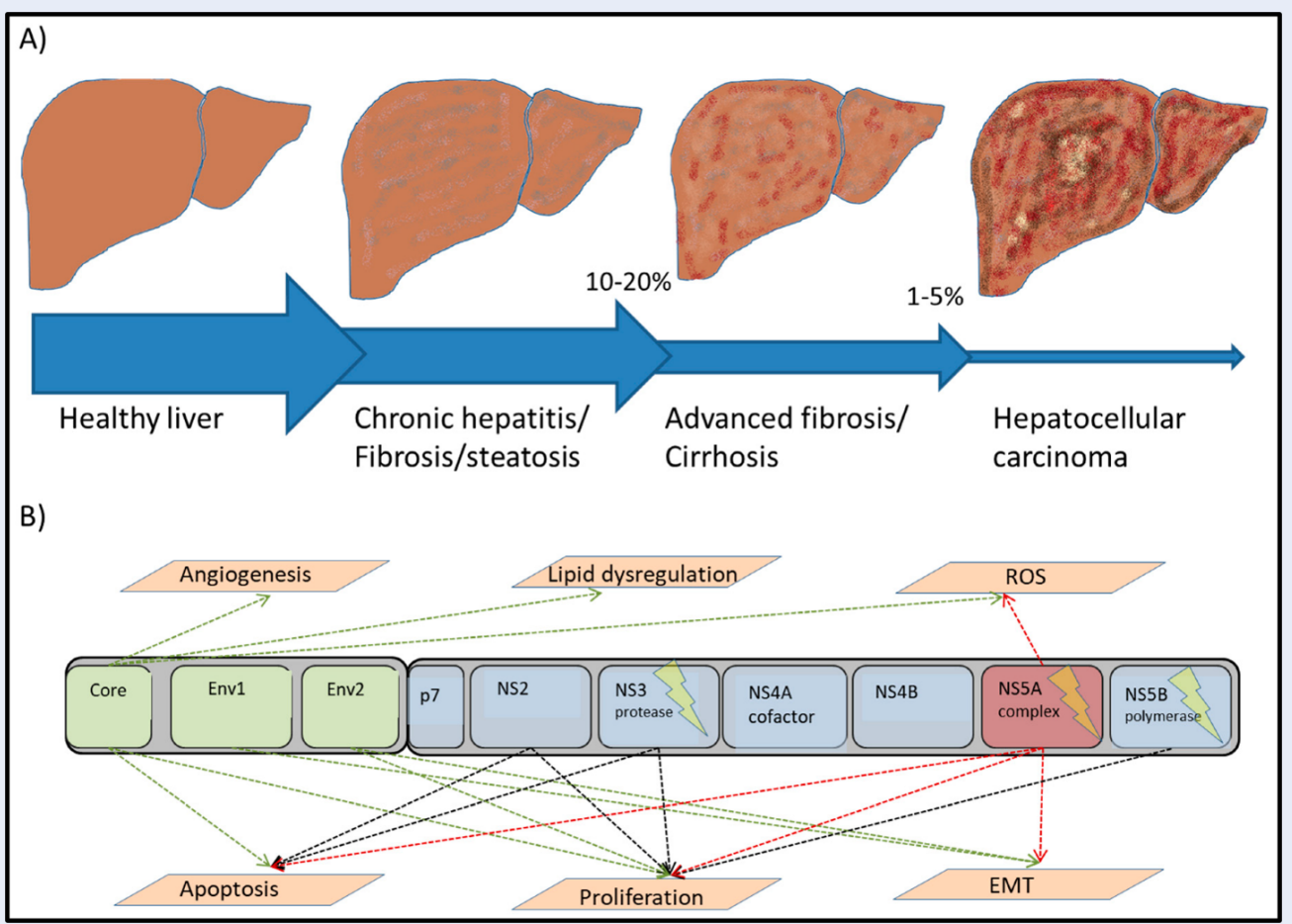

Figure 2: Mechanisms of Hepatitis C virus carcinogenesis from infection to hepatocellular carcinoma. A) Structural and non-structural proteins that play role in hepatocellular carcinoma B). Adapted from Hayes et al. $(2018)^{59}$. https://doi.org/10.6084/m9.figshare.16702450.v1

of various malignancies compared with the general population due to the progressive immune dysfunction ${ }^{69}$. Lung cancer is the most common HIV-related cancer, as demonstrated by many studies. However, the underlying mechanism of HIV is still poorly known $^{70,71}$. In one study ${ }^{72}$, the authors suggested that cancer patients who are infected with HIV have a poorer prognosis compared to non-infected cancer patients. It has been reported that approximately $40 \%$ of HIV-associated malignancies were found to be associated with other oncogenic viruses such as EBV, human herpesvirus, HPV, and hepatitis B and $\mathrm{C}$ viruses ${ }^{73}$. Kaposi's sarcoma is an angioproliferative tumor that results from the Human herpesvirus8 infection of cells of endothelial lineage in HIV patients ${ }^{74}$. Anampa et al. (2020) ${ }^{75}$ studied the mechanism of HIV carcinogenesis and reported that the viral infection itself appeared not to be directly involved in carcinogenesis. Instead, it disrupts the immune surveillance of tumors and other carcinogenic pathogens. The same authors reported that HIV induces cytokine dysregulation and genetic alterations, both of which enhance the potential for carcinogenesis. Furthermore, HIV is associated with chronic antigen stimulation which promotes lymphomagenesis $^{75}$.

Human $\mathrm{T}$ lymphotropic virus type $\mathrm{I}$ is a type of single-stranded RNA retrovirus characterized by slow transformation and associated with adult T-cell leukemia ${ }^{76}$. The genome of this virus contains two long-terminal repeats and encodes for several genes, such as flanking gag, env, and pol, in addition to other accessory genes. These genes have been postulated to play a significant role in tumorigenesis ${ }^{77}$. Several proteins in Human $\mathrm{T}$ lymphotropic virus type I have been demonstrated to play key roles in cancer induction through cellular transformation as well as the immortalization of infected $\mathrm{T}$ lymphocytes ${ }^{78}$. It is of note that the Human T lymphotropic virus type I oncoprotein Tax inhibits the innate IFN immune response by mediating an interaction between the mitochondrial antiviral-signaling protein, the stimulator of interferon, and the receptors interacting with protein 1 . This interaction causes the suppression of the TANK-binding kinase 1 enzyme-mediated phosphorylation of IFN regulatory factor 3/IFN regulatory factor $7^{79}$. The accessory protein of Human T lymphotropic virus, the leucine zipper factor, disrupts genomic integrity and inhibits apoptosis as well as the 
autophagy of the target cells. This leads to the enhancement of cell proliferation and facilitates its evasion from immune surveillance. This mediates oncogenesis $^{78}$.

\section{Carcinogenic bacteria}

Recently, a significant number of studies have implicated that different types of bacteria are involved in the etiology of some cancer types, including Helicobacter pylori in mucosa-associated lymphoid tissue cancer ${ }^{80}$ as well as gastric cancer ${ }^{81}$, Salmonella typhi in gallbladder cancer ${ }^{82}$, Bacteroides fragilis in colon cancer ${ }^{83}$, and Chlamydia trachomatis in cervical cancer $^{84}$. This has inspired researchers to further study the mechanisms through which these bacteria promote oncogenesis in order to provide evidence to support such a role. H. pylori is the most abundant bacterial species in the gastric epithelium due to its ability to resist and adapt to gastric acidity. Its presence has been markedly associated with the development of gastric and mucosa-associated lymphoid tissue cancers. A significant number of researchers have linked $H$. pylori infections with gastric cancer and mucosaassociated lymphoid tissue cancer ${ }^{85-88}$, considering it to be among the most important, if not the top, risk factor for gastric cancer in the world. Posselt et al. (2017) ${ }^{89}$ studied the mechanism of gastric cancer induction by $H$. pylori and reported that upon infection, the bacteria actively interferes with the host gastric cells via the secretion of bacterial proteases and the activation of cellular proteases. This may be involved in the induction of cancer. H. pylori regulates and controls the secretion of proteases and thus hosts cytokines in early and late pathogenesis ${ }^{90}$. It has been reported that $H$. pylori continuously induces various transcription factors and proteases, including disintegrin and metalloproteinase (ADAM) and various types of matrix metalloproteinases (MMPs). It can highly secrete the host cytokines and interfere with the extracellular matrix proteins or lateral junction complexes ${ }^{91}$. The chronic ulceration that results from $H$. pylori pathogenesis will eventually lead to cell proliferation and the formation of tumors ${ }^{89}$. Figure 3 summarizes the mechanisms of gastric cancer induction by $H$. pylori.

Alfarouk et al. (2019) ${ }^{\mathbf{9 2}}$ studied the possible role of $H$. pylori in gastric cancer and revealed that the carcinogenicity of such bacteria depends on bacteria-host related factors. They reported several genes expressed by the bacteria that accelerate its pathogenicity, in addition to the remodeling of the microenvironment including urease, carbonic anhydrase, Lewis antigen,
$\operatorname{vacA}, \operatorname{cagA}$, and babA2. The variety of these virulence factors as mucys in $H$. pylori helps to stabilize its population size in the stomach. This leads to the induction of chronic inflammation ${ }^{93}$. This creates an unfavorable habitat that alters the $\mathrm{pH}$ due to the chronic inflammation around the normal gastric cells. This instigates their malignant transformation and provides an accurate marker of gastric cancer ${ }^{\mathbf{9 4}, 95}$. The transformation of gastric cells might be our bodies' normal defense against $H$. pylori as various environmental changes elicit phenotypic plasticity in the gastric cells, enabling them to take on acidophilic phenotypes.

B. fragilis has been reported to be one of the major causes of colorectal cancer ${ }^{96}$. In one study, Chen et al. (2020) ${ }^{83}$ reported that $B$. fragilis accelerates colonization by producing a biofilm in the intestinal tract. This causes a series of inflammatory reactions that result from toxin production. The accumulation of B. fragilis toxin may lead to severe tissue injury and chronic intestinal inflammation which may then develop into colorectal cancer. Snezhkina et al. ${ }^{97}$ investigated the mechanisms of colorectal cancer formation by $B$. fragilis and found that bacterial enterotoxins are able to activate spermine oxidase from the host cells. This produces $\mathrm{H}_{2} \mathrm{O}_{2}$ and spermidine as the byproducts of polyamine catabolism. These compounds significantly induce an inflammatory response leading to tissue injury and disturbance. The same authors found two mediators, namely c-Myc and $\mathrm{C} / \mathrm{EBP} \beta$ to be overexpressed in tumors. These mediators play a significant role in cell proliferation, inflammation, and metabolic reprogramming.

S. typhi is another pathogenic bacteria that has been linked to the malignant transformation of the gallbladder $^{98}$. S. typhi has the potential to promote carcinogenesis due to the production of various secretions such as nitroso compounds, bacterial glucuronidase, and toxic molecules. Cytolethal distending toxins are groups of toxins produced by $S$. $t y$ phi that are able to trigger irreversible cell cycle arrest and apoptosis resulting from DNA damage ${ }^{99}$. Di Domenico et al. (2017) ${ }^{\mathbf{1 0 0}}$ reported that the typhoid toxin produced by $S$. typhi has strong carcinogenic potential as it induces DNA damage which leads to various alterations in the cell cycle of intoxicated cells ${ }^{101}$. Furthermore, the biofilm production of $S$. typhi has been linked to tumorigenesis by promoting a persistent infection in the gallbladder. This leads to a chronic local inflammatory response that exposes the epithelial cells to severe and repeated damage. The presence of chronic infection around gallstones may enhance the formation of an S. typhi biofilm, allowing 


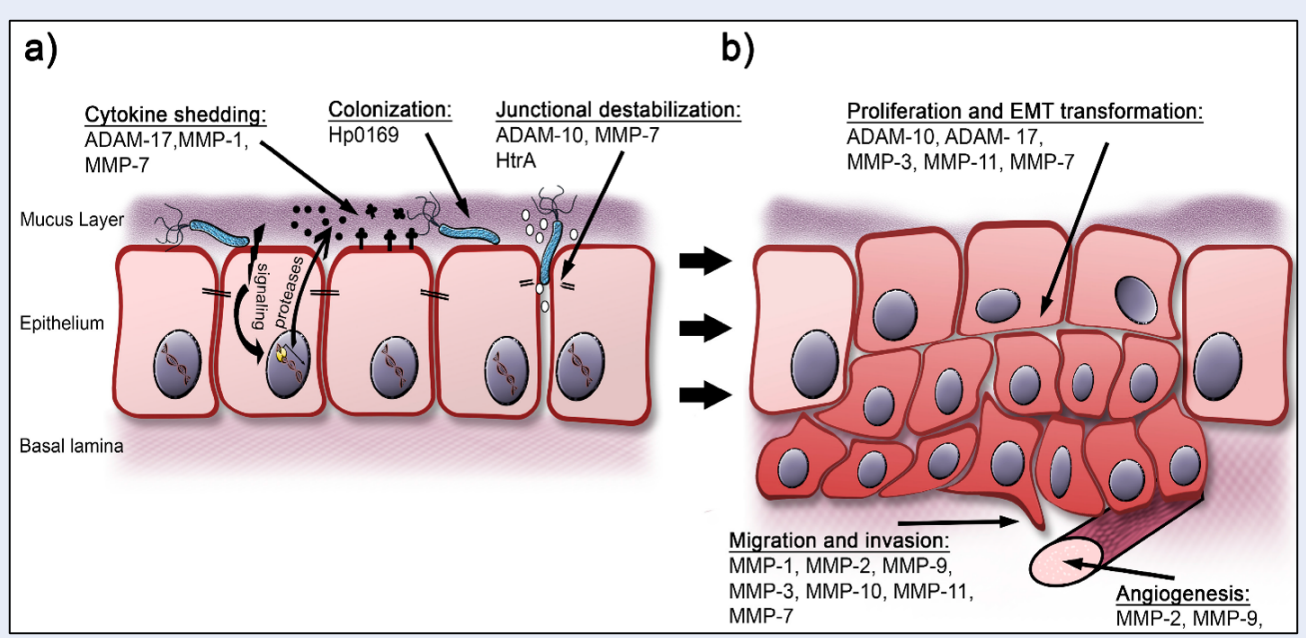

Figure 3: Mechanisms of gastric cancer induction by H. pylori. A) Secretion of various transcription factors which can directly shed cytokines. B) Advanced stage of infection where proteases are implicated in cell proliferation and tumorigenesis. Adapted from Posselt et al. (2017) ${ }^{89}$. https://doi.org/10.6084/m9.figshare.167024 53.v1

the bacterial cells to detach from the gallstones and release various carcinogenic molecules. This induce genomic instability in the gallbladder epithelial cells and leads to tumorigenesis ${ }^{100}$. Figure 4 presents the proposed mechanisms by which $S$. typhi may induce gallbladder cancer.

C. trachomatis has been reported to be involved in the process of cell proliferation and the inhibition of apoptosis. The induction of chronic inflammation by C. trachomatis and the same as a potential cause of cervical cancer was studied by Zhu et al. (2016) ${ }^{\mathbf{8 4}}$. The authors concluded that individuals infected with C. trachomatis have a significantly higher risk of cervical cancer. In a different study, Laban et al. (2019) ${ }^{102}$ evaluated the association of $C$. trachomatis infection with high-grade serous ovarian cancers and tubal carcinoma. The authors detected bacterial DNA in $84 \%$ of high-grade tubal serous cancers which revealed the strong relationship between C. trachomatis and this type of cancer. Although these findings have not yet been supported by a suggested mechanism of carcinogenicity, these findings need to be replicated and further investigated to understand the potential role of C. trachomatis in ovarian and cervical cancers.

\section{Carcinogenic parasites}

The associations between parasitic infections and cancers have been well established in numerous studies 103-106 (103-106). Schistosoma haematobium, Clonorchis sinensis, and Opistorchis viverrini have been reported to be among the most carcinogenic parasites $^{\mathbf{1 0 7}}$, whereas other infectious species have been linked due to being the potential cause of cancers, especially the genera Schistosoma and Opisthorchis ${ }^{108}$. Many mechanisms have been suggested for carcinogenic parasites. Among them, 3 have been described for liver flukes, including metabolic oxidative stress, chronic inflammation, and tissue damage due to parasitic attack ${ }^{109}$. Van Tong et al. (2017) ${ }^{110}$ studied the relationship between carcinogenesis and human malignancy in different parasites and revealed the high carcinogenicity of 3 helminth diseases including schistosomiasis, clonorchiasis, and opisthorchiasis. The authors illustrated the proposed mechanisms for cancer induction as presented in Figure 5. The chronic inflammation induced by the parasitic infections leads to the enhanced activation of many signaling pathways. This eventually generate somatic mutations that may activate oncogenes ${ }^{111}$.

The metabolite secretions of Opisthorchis, Clonorchis, and Schistosoma species into the microenvironment of the host may induce metabolic processes such as oxidative stress which facilitates chromosomal DNA damage of the host cells, leading them to becoming cancerous ${ }^{113}$. The physical damage of host tissues due to parasitic attack, together with the immune response and wound healing process, lead to the secretion of various cytokines to increase cell proliferation and transformation. This also increases the potential for DNA damage and/or mutations ${ }^{114}$. Combined parasite-host interaction events, namely physi- 


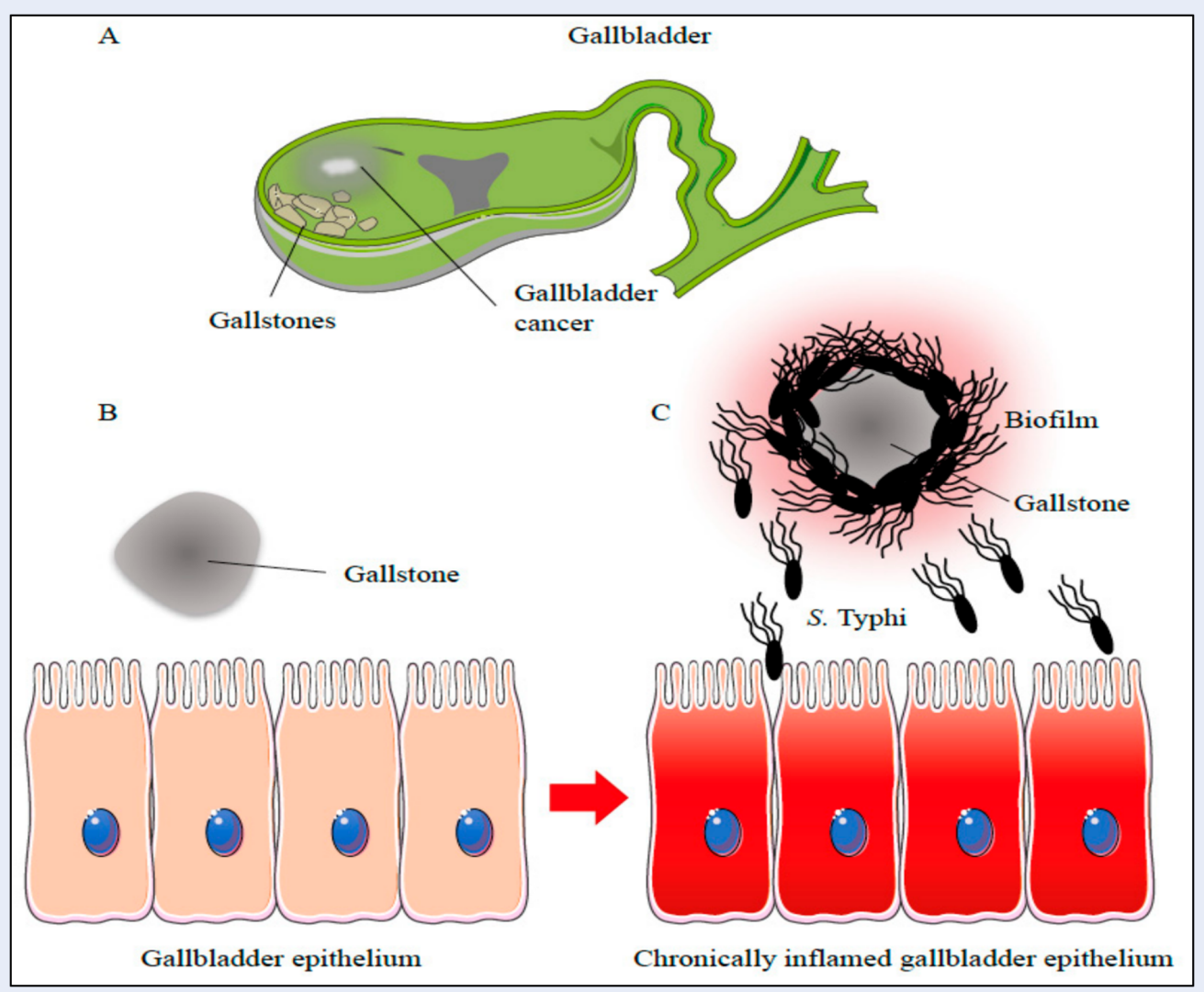

Figure 4: Proposed mechanisms for the induction of gallbladder cancer by S. typhi. (A) Chronic infection with S. typhi strains in the presence of gallstones. (B) Gallstones enhance the biofilm formation of S. typhi. (C) Bacterial cells detach from gallstones and release carcinogenic molecules. Adapted from Di Domenico et al. (2017) ${ }^{100}$. htt ps://doi.org/10.6084/m9.figshare.16702462.v1

cal damage, parasite-derived products and chronic inflammation, as well as the combined effects on these processes on the host tissue and their DNA, leads to significant modifications and a higher risk of carcinogenesis due to changes in the cells' growth rate and proliferation, in addition to their survival. This in turn may initiate tumorigenesis and promote malignancy ${ }^{110}$. Table 1 summarizes the parasites that have been linked to different types of cancers and the proposed mechanism of carcinogenesis for each.

\section{Carcinogenic fungi}

Recent studies have revealed that fungi in the human gut can move into the pancreas under certain circumstances, triggering changes in the pancreatic cells that can lead to tumorigenesis ${ }^{\mathbf{1 2 6}}$. Aykut et al. (2019) ${ }^{127}$ found that the fungal component of the pancreatic microbiome are significantly altered in pancreatic ductal adenocarcinoma. In fact, several fungal genera promote tumor formation. Similarly, Malik et al. (2018) ${ }^{\mathbf{1 2 8}}$ found that common resident gut fungi can promote the activation of inflammasome during azoxymethane/dextran sodium sulfate-induced colitis in a mouse model. The authors reported that such fungi were able to alter the cell signaling during inflammasome activation. This resulted in the secretion of various cytokines including interleukin (IL)-18 and interferon- $\gamma$, suggesting that during spleen tyrosine kinase-caspase recruitment, domain-9 signaling maintains a microbialor specifically fungal-ecology that promotes the activation of inflammasome and thus restrains colitis and colon tumorigenesis ${ }^{128}$. Malassezia species are the most common fungal species in mammalian skin, and they are the best-studied fungal species in skin conditions include atopic dermatitis and dandruff ${ }^{129}$. Some studies have reported that inflammation caused by the overgrowth of Malassezia may worsen gastric ulcers, weakening the immune system and changing the cell-surface signaling ${ }^{\mathbf{1 3 0}-\mathbf{1 3 3}}$. Therefore, an abundance of Malassezia species in pancreatic ductal adenocarcinoma tumors may be medically relevant. 


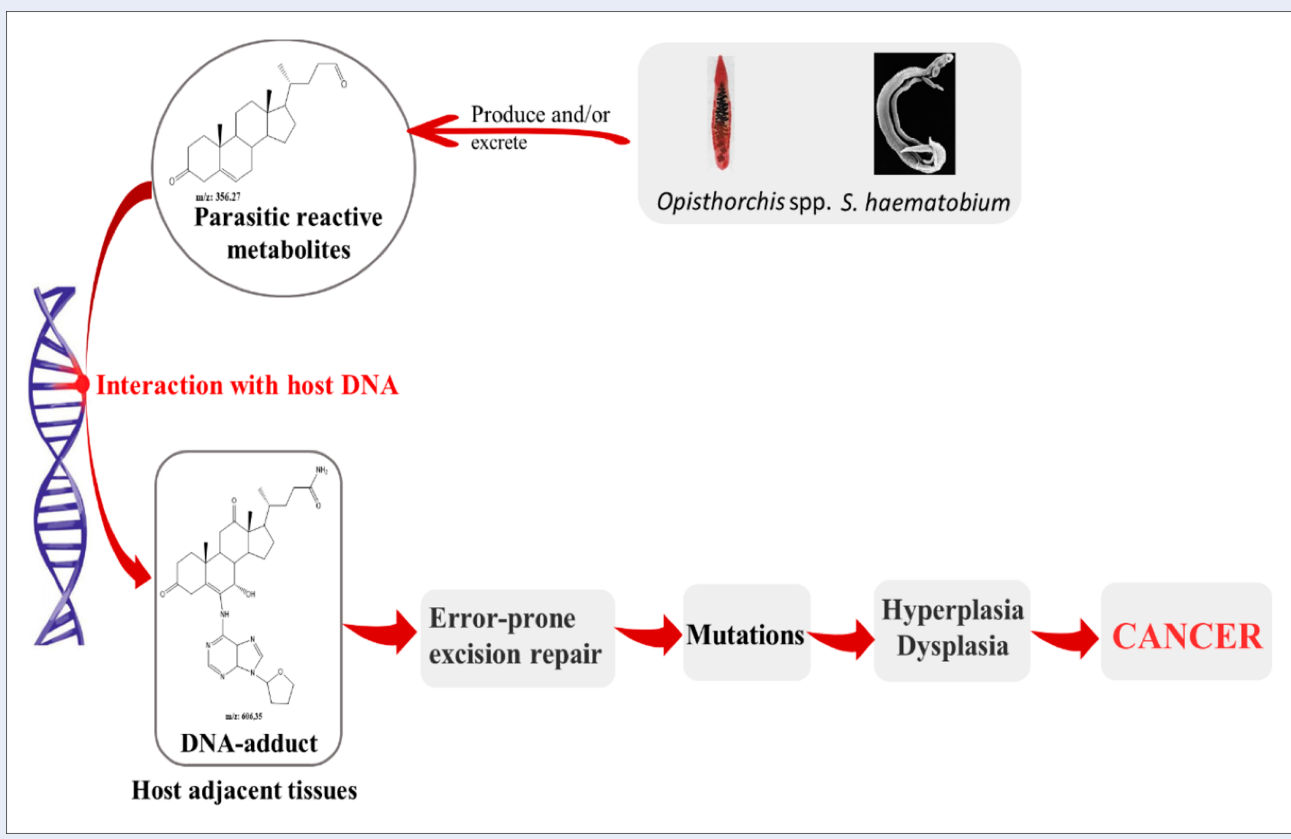

Figure 5: Proposed carcinogenic mechanisms of S. haematobium and O. viverrini. Adapted from Vale et al. (2020) ${ }^{112}$. https://doi.org/10.6084/m9.figshare.16702465.v1

Aykut et al. (2019) ${ }^{\mathbf{1 2 7}}$ found that the administration of antifungal drugs halted pancreatic ductal adenocarcinoma progression in mouse models and significantly improved the ability of chemotherapy, leading to significant shrinking of the tumors. Interestingly, the subsequent repopulation of healed lab animals by a Malassezia fungal species significantly accelerated the growth of pancreatic ductal adenocarcinoma again ${ }^{134}$. Not much work has considered the relationship between different fungi and cancers but these findings suggests that any microorganism is able to change the normal nature of the human body, making it a potential cause of cancer.

\section{CANCER PREVENTION AND HEALTH PRECAUTIONS}

In the age of personalized medicine and selftreatment, it is extremely important to isolate the causes of health issues to effectively plan personalized therapy. Various epidemiological studies have revealed that leisure time and physical activity can significantly reduce and even prevent at least 13 types of cancer ${ }^{95,135}$. Other studies have provided evidence that exercise significantly reduces the risk of developing breast, colon, and prostate cancers ${ }^{136,137}$. The nature and duration of exercise training involves wholebody homeostasis. This leads to the widespread adaptation of the body's cells, tissues, and organs ${ }^{138,139}$.
Various systemic factors such as the release of catecholamines and myokines during exercise, in addition to sympathetic activation, shear stress, increase blood flow, and an increase body temperature. All immediately exert stress on tumor metabolism and homeostasis $\mathbf{1 4 0 , 1 4 1}$. These acute effects in the long-term will lead to improved blood perfusion, metabolism adjustments, enhanced immunogenicity, and intratumoral adaptations, contributing to slower tumor progression ${ }^{142}$. Various probiotic strains have been used to treat microbial infections, especially gastrointestinal tract infections, to boost human health as well as to control the biofilm formation that may lead to tumorigenesis ${ }^{143}$. Jacouton et al. (2017) ${ }^{144}$ evaluated the role of Lactobacillus casei in colorectal cancer prevention and revealed that it had an immunomodulatory effect mediated by the regulation of different cytokines (particularly IL-22). This was in addition to an antiproliferative effect mediated by Bik, caspase- 7 and caspase- 9 regulation. The authors suggested using these probiotics in food supplements as a promising strategy for cancer prevention. In a different study, anti-biofilm properties were evaluated in cocktails of probiotic strains against $B$. fragilis and Escherichia coli strains. They were demonstrated to be highly preventive of tumorigenesis inflammation ${ }^{145,146}$. Hindering the biofilm formation of pathogenic gut microbes is said to be an effective method of cancer prevention for which certain 
Table 1: Mechanism of carcinogenesis of parasitic pathogens

\begin{tabular}{|c|c|c|c|c|}
\hline Parasitic pathogens & Disease & Associated cancer & $\begin{array}{l}\text { Proposed mechanism of } \\
\text { carcinogenesis }\end{array}$ & Refs \\
\hline $\begin{array}{l}\text { Cryptosporidium } \\
\text { parvum }\end{array}$ & Cryptosporidiosis & Colorectal cancer & $\begin{array}{l}\text { Inhibit apoptosis and enhance } \\
\text { cells proliferation }\end{array}$ & 115 \\
\hline Schistosoma mansoni & Schistosomiasis & $\begin{array}{l}\text { Colorectal cancer and } \\
\text { hepatocellular } \\
\text { carcinoma }\end{array}$ & $\begin{array}{l}\text { Chronic inflammation, and } \\
\text { oxidative stress }\end{array}$ & 116 \\
\hline $\begin{array}{l}\text { Schistosoma } \\
\text { japonicum }\end{array}$ & Schistosomiasis & $\begin{array}{l}\text { Colorectal cancer and } \\
\text { squamous cell } \\
\text { carcinoma }\end{array}$ & $\begin{array}{l}\text { Chronic inflammation, and } \\
\text { oxidative stress }\end{array}$ & 117 \\
\hline $\begin{array}{l}\text { Schistosoma } \\
\text { haematobium }\end{array}$ & Schistosomiasis & $\begin{array}{l}\text { Urinary bladder } \\
\text { cancer, squamous cell } \\
\text { carcinoma }\end{array}$ & $\begin{array}{l}\text { Chronic inflammation, and } \\
\text { oxidative stress }\end{array}$ & 118 \\
\hline Blastocystis hominis & $\begin{array}{l}\text { Blastocystis } \\
\text { infection }\end{array}$ & Colorectal cancer & $\begin{array}{l}\text { Signaling induction, leading to } \\
\text { impaired apoptosis }\end{array}$ & 119 \\
\hline Toxoplasma gondii & Toxoplasmosis & $\begin{array}{l}\text { Brain cancer, menin- } \\
\text { gioma and glioma }\end{array}$ & $\begin{array}{l}\text { Triggering a chronic } \\
\text { inflammatory and alteration of } \\
\text { cell }\end{array}$ & 120 \\
\hline Clonorchis sinensis & Clonorchiasis & Cholangiocarcinoma & $\begin{array}{l}\text { Chronic inflammation, cell } \\
\text { proliferation \& oxidative stress }\end{array}$ & 121 \\
\hline $\begin{array}{l}\text { Trichomonas } \\
\text { vaginalis }\end{array}$ & $\begin{array}{l}\text { Vaginitis and } \\
\text { urethritis }\end{array}$ & $\begin{array}{l}\text { Prostate, cervical and } \\
\text { reproductive tract, } \\
\text { cancers }\end{array}$ & $\begin{array}{l}\text { Triggering of proto-oncogenes } \\
\text { and altering junctional protein } \\
\text { expression }\end{array}$ & 122 \\
\hline $\begin{array}{l}\text { Plasmodium } \\
\text { falciparum }\end{array}$ & Malaria & Burkitt lymphoma & $\begin{array}{l}\text { Immune suppression for } \\
\text { carcinogenic viruses }\end{array}$ & 123 \\
\hline Opistorchis viverrini & Opisthorchiasis & Cholangiocarcinoma & $\begin{array}{l}\text { Chronic inflammation, cell } \\
\text { proliferation \& oxidative stress }\end{array}$ & 124 \\
\hline Taenia solium & Neurocysticercosis & Gliomas & $\begin{array}{l}\text { Chronic inflammation and } \\
\text { cellular proliferation }\end{array}$ & 125 \\
\hline
\end{tabular}

strains of probiotic can be utilized ${ }^{147,148}$. The production of antagonistic compounds, the modulation of the host immune responses, and competition with pathogens are among the mechanisms that have been suggested due to the beneficial role that probiotics appear to play, as Figure 6 illustrates ${ }^{149}$. Natural products have been screened for their anticancer properties, and many have been used in the development of cancer preventive and anticancer drugs ${ }^{150}$. Most anticancer drugs that have been approved by the Food and Drug Administration of the United States are either natural or they mimic natural products ${ }^{151}$. Song et al. (2016) ${ }^{152}$ reported that the prevention of any disease requires either the avoidance or reduction of risk factors (i.e., carcinogenic materials or microorganisms) or the early detection of and intervention in disease evolution. In this regard, following a natural diet regime and avoiding oxidants and synthetic materials are major factors that may limit tumorigenesis in addition to boosting the immune system to help combat carcinogenic microorganisms. Figure 6 presents the mechanisms by which probiotics target tumorigenic gut microbial biofilms.

\section{CONCLUSION}

Recent research has uncovered a great deal of information regarding the mechanisms used by different microorganisms to cause, colonize, or cure cancer. However, many questions remain. It has long been known that many microorganisms can trigger tumorigenesis in humans but to date, the exact molecular mechanisms of many of these microbes have remained unclear. The continued exploration of these questions will bring research ever closer to the prevention, early diagnosis, and truly effective treatment of this scourge of mankind. Here we have discussed 


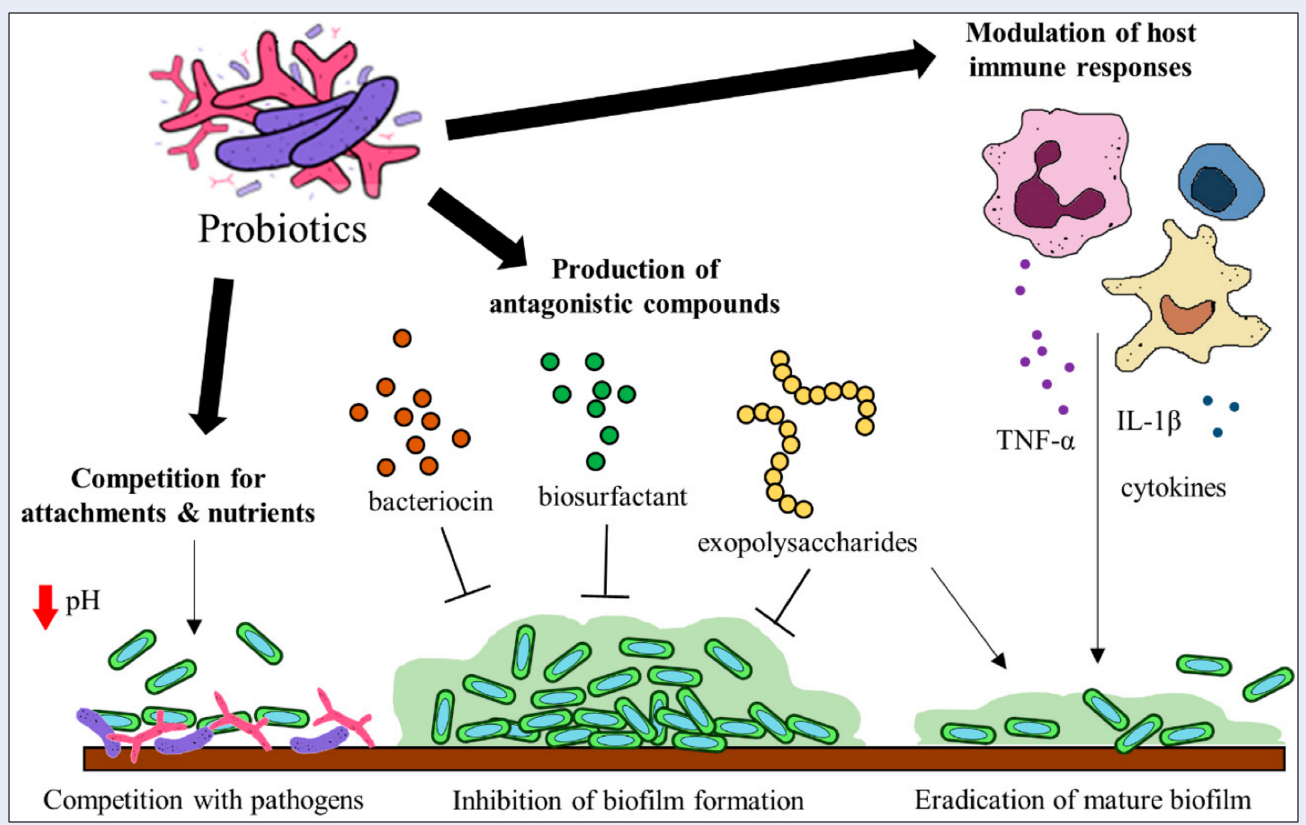

Figure 6: Schematic illustration of probiotic mechanisms targeting tumorigenic gut microbial biofilms Adapted from Chew et al. (2020) ${ }^{153}$. https://doi.org/10.6084/m9.figshare.16702468.v1

the role of viruses, bacteria, protozoa, and fungi in tumorigenesis and elucidated the possible molecular events that may be involved in the carcinogenic properties of each type of pathogen. We have also explored the structural basis for how the host cells interact with these microorganisms to produce the hallmarks of cancer. Microbial secretions, as well as immuneregulating cytokines, may play an essential role as mutagenic factors.

\section{ABBREVIATIONS}

AIDS: Acquired immunodeficiency syndrome

DNA: Deoxyribonucleic acid

EBV: Epstein-Barr virus

HCC: Hepatocellular carcinoma

HIV: Human immunodeficiency virus

HPV: Human papilloma virus

IL: Interleukin

ROS: Reactive oxygen species

\section{ACKNOWLEDGMENTS}

The authors would like to thank the collaboration between Sabratha University, Sabratha, Libya, University Teknologi MARA, Shah Alam, Malaysia and the Universiti Sains Malaysia, Penang, Malaysia that made this work possible.

\section{AUTHOR'S CONTRIBUTIONS}

All authors contributed equally to this work. All authors read and approved the final manuscript.

\section{FUNDING}

None.

\section{AVAILABILITY OF DATA AND MATERIALS}

Not applicable.

\section{ETHICS APPROVAL AND CONSENT TO PARTICIPATE}

Not applicable.

\section{CONSENT FOR PUBLICATION}

Not applicable.

\section{COMPETING INTERESTS}

The authors declare that they have no competing interests.

\section{REFERENCES}

1. Jaiswal R, Sedger LM. Intercellular vesicular transfer by exosomes, microparticles and oncosomes-implications for cancer biology and treatments. Front Oncol. 2019;9:125. PMID: 30895170. Available from: 10.3389/fonc.2019.00125.

2. Banu A, Gousuddin M, Yahya EB. Green synthesized monodispersed silver nanoparticles' characterization and their efficacy against cancer cells. Biomed Res Ther. 2021;8(8):4476-82. Available from: 10.15419/bmrat.v8i8.686. 
3. Araldi RP, Sant'Ana TA, Módolo DG, de Melo TC, SpadacciMorena DD, de Cassia Stocco R. The human papillomavirus (HPV)-related cancer biology: an overview. Biomed Pharmacother. 2018;106:1537-56. PMID: 30119229. Available from: 10.1016/j.biopha.2018.06.149.

4. Wong SH, Kwong TNY, Wu CY, Yu J. Clinical applications of gut microbiota in cancer biology. Semin Cancer Biol. 2019;55:2836. PMID: 29782923. Available from: 10.1016/j.semcancer. 2018.05.003.

5. Russo E, Taddei A, Ringressi MN, Ricci F, Amedei A. The interplay between the microbiome and the adaptive immune response in cancer development. Therap Adv Gastroenterol. 2016;9(4):594-605. PMID: 27366226. Available from: $10.1177 / 1756283 X 16635082$.

6. Sethi V, Kurtom S, Tarique M, Lavania S, Malchiodi Z, Hellmund L, et al. Gut Microbiota Promotes Tumor Growth in Mice by Modulating Immune Response. Gastroenterology. 2018;155(1):33-37.e6. PMID: 29630898. Available from: 10.1053/j.gastro.2018.04.001.

7. O'Keefe SJ. Diet, microorganisms and their metabolites, and colon cancer. Nat Rev Gastroenterol Hepatol. 2016;13(12):691-706. PMID: 27848961. Available from: 10.1038/nrgastro.2016.165.

8. Reinhardt $C$, Bergentall $M$, Greiner TU, Schaffner $F$, Ostergren-Lundén G, Petersen LC. Tissue factor and PAR1 promote microbiota-induced intestinal vascular remodelling. Nature. 2012;483(7391):627-31. PMID: 22407318. Available from: 10.1038/nature10893.

9. Wu S, Rhee KJ, Albesiano E, Rabizadeh S, Wu X, Yen HR. A human colonic commensal promotes colon tumorigenesis via activation of $\mathrm{T}$ helper type $17 \mathrm{~T}$ cell responses. Nat Med. 2009;15(9):1016-22. PMID: 19701202. Available from: 10.1038/nm.2015

10. Louis P, Hold GL, Flint HJ. The gut microbiota, bacterial metabolites and colorectal cancer. Nat Rev Microbiol. 2014;12(10):661-72. PMID: 25198138. Available from: 10. 1038/nrmicro3344.

11. Nougayrède JP, Homburg $S$, Taieb F, Boury M, Brzuszkiewicz E, Gottschalk G. Escherichia coli induces DNA double-strand breaks in eukaryotic cells. Science. 2006;313(5788):848-51. PMID: 16902142. Available from: 10.1126/science.1127059.

12. Yahya EB, Alqadhi AM. Recent trends in cancer therapy: A review on the current state of gene delivery. Life Sci. 2021;269:119087. PMID: 33476633. Available from: 10.1016/ j.lfs.2021.119087.

13. Swanson MS, Kokot N, Sinha UK. The role of HPV in head and neck cancer stem cell formation and tumorigenesis. Cancers (Basel). 2016;8(2):24. PMID: 26907349. Available from: 10. 3390/cancers8020024.

14. Kalisperati P, Spanou E, Pateras IS, Korkolopoulou P, Varvarigou A, Karavokyros I. Inflammation, DNA damage, Helicobacter pylori and gastric tumorigenesis. Front Genet. 2017;8:20. PMID: 28289428. Available from: 10.3389/fgene. 2017.00020.

15. Callejas BE, Martínez-Saucedo D, Terrazas LI. Parasites as negative regulators of cancer. Biosci Rep. 2018;38(5). PMID: 30266743. Available from: 10.1042/BSR20180935.

16. Wang $Y$, Zhang D, Hou Y, Shen S, Wang T. The adaptor protein CARD9, from fungal immunity to tumorigenesis. Am J Cancer Res. 2020;10(8):2203-25. PMID: 32905547.

17. Dzutsev A, Goldszmid RS, Viaud S, Zitvogel L, Trinchieri G. The role of the microbiota in inflammation, carcinogenesis, and cancer therapy. Eur J Immunol. 2015;45(1):17-31. PMID: 25328099. Available from: 10.1002/eji.201444972.

18. Vinasco K. Microbial carcinogenesis: lactic acid bacteria in gastric cancer. Biochimica et Biophysica Acta (BBA)-. Rev Can. 2019;1872(2):188309.

19. Elinav E, Nowarski R, Thaiss CA, Hu B, Jin C, Flavell RA. Inflammation-induced cancer: crosstalk between tumours, immune cells and microorganisms. Nat Rev Cancer. 2013;13(11):759-71. PMID: 24154716. Available from: 10.
$1038 / \operatorname{nrc} 3611$.

20. Goodman B, Gardner H. The microbiome and cancer. J Pathol. 2018;244(5):667-76. PMID: 29377130. Available from: 10.1002 /path.5047.

21. de Martel C, Ferlay J, Franceschi S, Vignat J, Bray F, Forman D. Global burden of cancers attributable to infections in 2008: a review and synthetic analysis. Lancet Oncol. 2012;13(6):60715. PMID: 22575588. Available from: 10.1016/S1470-2045(12) 70137-7.

22. Cancer IA, on the Evaluation of Carcinogenic Risks to Humans IWG. Biological agents. Volume 100 B. A review of human carcinogens. IARC Monogr Eval Carcinog Risks Hum. 2012;100:1-441. PMID: 23189750.

23. Saleh A, Halawa A. Is BK virus carcinogenic? Nephrology Dialysis Transplantation. 2020;35(Supplement_3):gfaa142.P1649. Available from: 10.1093/ndt/ gfaa142.P1649.

24. Yaghoubi A, Khazaei M, Jalili S, Hasanian SM, Avan A, Soleimanpour $S$, et al. Bacteria as a double-action sword in cancer. Biochim Biophys Acta Rev Cancer 2020;1874(1):188388. Available from: 10.1016/j.bbcan.2020. 188388.

25. Klimesova K, Zakostelska ZJ, Tlaskalova-Hogenova H. Oral bacterial and fungal microbiome impacts colorectal carcinogenesis. Front Microbiol. 2018;9:774. PMID: 29731748. Available from: 10.3389/fmicb.2018.00774.

26. Mukherjee A. A Systematic Review on Parasite In duced Carcinogenesis. International Journal of Innovative Science and Research Technology. 2020;5(6):10951099. Available from: https://ijisrt.com/a-systematic-reviewon-parasite-induced-carcinogenesis.

27. Rous P. A sarcoma of the fowl transmissible by an agent separable from the tumor cells. J Exp Med. 1911;13(4):397-411. PMID: 19867421. Available from: 10.1084/jem.13.4.397.

28. Epstein MA, Achong BG, Barr YM. Virus particles in cultured lymphoblasts from Burkitt's lymphoma. Lancet. 1964;1(7335):702-3. PMID: 14107961. Available from: 10. 1016/S0140-6736(64)91524-7.

29. Pagano JS. Epstein-Barr virus: the first human tumor virus and its role in cancer. Proc Assoc Am Physicians. 1999;111(6):573-80. PMID: 10591086. Available from: 10. 1046/j.1525-1381.1999.t01-1-99220.x.

30. Rodriguez-Acevedo AJ, Green AC, Sinclair C, van Deventer E, Gordon LG. Indoor tanning prevalence after the International Agency for Research on Cancer statement on carcinogenicity of artificial tanning devices: systematic review and meta-analysis. Br J Dermatol. 2020;182(4):849-59. PMID: 31381131. Available from: 10.1111/bjd.18412.

31. Yahya EB, Alqadhi AM, Abdulsamad MA, Allaq AA. Asian Nipah virus and the potential of new pandemic. Pakistan Journal of Biotechnology. 2021;18(1-2):17-22. Available from: 10.34016/pjbt.2021.18.1.17.

32. Zapatka M, Borozan I, Brewer DS, Iskar M, Grundhoff A, Alawi $M$, et al. The landscape of viral associations in human cancers. Nat Genet. 2020;52(3):320-30. PMID: 32025001. Available from: $10.1038 / \mathrm{s} 41588-019-0558-9$.

33. Hausen HZ. Human papillomaviruses and their possible role in squamous cell carcinomas. Curr Top Microbiol Immunol. 1977;78:1-30. PMID: 202434. Available from: 10.1007/9783-642-66800-5_1.

34. Bukhari N, Joseph JP, Hussain SS, Khan MA, Wakim MJ, Yahya EB. Prevalence of Human Papilloma Virus Sub Genotypes following Head and Neck Squamous Cell Carcinomas in Asian Continent, A Systematic Review Article. Asian Pac J Cancer Prev. 2019;20(11):3269-77. PMID: 31759348. Available from: 10.31557/APJCP.2019.20.11.3269.

35. von Knebel Doeberitz M, Oltersdorf T, Schwarz E, Gissmann L. Correlation of modified human papilloma virus early gene expression with altered growth properties in C4-1 cervical carcinoma cells. Cancer Res. 1988;48(13):3780-6. PMID: 2837324. 
36. Baez CF, Gonçalves MT, da Rocha WM, de Souza LM, SavassiRibas F, de Oliveira Almeida NK. Investigation of three oncogenic epitheliotropic viruses shows human papillomavirus in association with non-melanoma skin cancer. Eur J Clin Microbiol Infect Dis. 2019;38(6):1129-33. PMID: 30788731. Available from: 10.1007/s10096-019-03508-z.

37. Wood O, Woo J, Seumois G, Savelyeva N, McCann KJ, Singh $D$, et al. Gene expression analysis of TIL rich HPV-driven head and neck tumors reveals a distinct B-cell signature when compared to HPV independent tumors. Oncotarget. 2016;7(35):56781-97. PMID: 27462861. Available from: 10. 18632/oncotarget.10788.

38. Thida M, Okada S, Shwe MM, Thu HM, Aye KS, Myint AA, et al. Determination of oncogenic human papillomavirus (HPV) genotypes in Anogenital cancers in Myanmar. Acta Med Okayama. 2016;70(2):103-10. PMID: 27094835. Available from: 10.18926/AMO/5418.

39. Rusan M, Li YY, Hammerman PS. Genomic landscape of human papillomavirus-associated cancers. Clin Cancer Res. 2015;21(9):2009-19. PMID: 25779941. Available from: 10. 1158/1078-0432.CCR-14-1101.

40. Langsfeld E, Laimins LA. Human papillomaviruses: research priorities for the next decade. Trends Cancer. 2016;2(5):23440. PMID: 27617309. Available from: 10.1016/j.trecan.2016. 04.001 .

41. Lambert PF, Münger $K$, Rösl F, Hasche $D$, Tommasino $M$. Beta human papillomaviruses and skin cancer. Nature. 2020;588(7838):20-1. PMID: 33328661. Available from: 10.1038/s41586-020-3023-0.

42. Morgan EL, Macdonald A. Manipulation of JAK/STAT signalling by high-risk HPVs: potential therapeutic targets for HPV-associated malignancies. Viruses. 2020;12(9):977. PMID: 32899142. Available from: 10.3390/v12090977.

43. Amirian ES, Scheurer ME. Chromosomally-integrated human herpesvirus 6 in familial glioma etiology. Med Hypotheses. 2012;79(2):193-6. PMID: 22591997. Available from: 10.1016/ j.mehy.2012.04.033.

44. Ganem D. KSHV and the pathogenesis of Kaposi sarcoma: listening to human biology and medicine. J Clin Invest. 2010;120(4):939-49. PMID: 20364091. Available from: 10. $1172 /$ JCI40567.

45. Li T, Ju E, Gao SJ. Kaposi sarcoma-associated herpesvirus miRNAs suppress CASTOR1-mediated mTORC1 inhibition to promote tumorigenesis. J Clin Invest. 2019;129(8):3310-23. PMID: 31305263. Available from: 10.1172/JCI127166.

46. Choi UY, Lee JJ, Park A, Zhu W, Lee HR, Choi YJ. Oncogenic human herpesvirus hijacks proline metabolism for tumorigenesis. Proc Natl Acad Sci USA. 2020;117(14):8083-93. PMID: 32213586. Available from: 10.1073/pnas.1918607117.

47. Kang S, Myoung J. Primary lymphocyte infection models for KSHV and its putative tumorigenesis mechanisms in B cell lymphomas. J Microbiol. 2017;55(5):319-29. PMID: 28455586. Available from: 10.1007/s12275-017-7075-2.

48. Gramolelli S, Ojala PM. Kaposi's sarcoma herpesvirusinduced endothelial cell reprogramming supports viral persistence and contributes to Kaposi's sarcoma tumorigenesis. Curr Opin Virol. 2017;26:156-62. PMID: 29031103. Available from: 10.1016/j.coviro.2017.09.002.

49. Rossi C, Butt ZA, Wong S, Buxton JA, Islam N, Yu A, et al. Hepatitis $C$ virus reinfection after successful treatment with direct-acting antiviral therapy in a large population-based cohort. J Hepatol. 2018;69(5):1007-14. PMID: 30142429. Available from: 10.1016/j.jhep.2018.07.025.

50. Ramsey SD, Unger JM, Baker LH, Little RF, Loomba R, Hwang JP. Prevalence of hepatitis $B$ virus, hepatitis $C$ virus, and HIV infection among patients with newly diagnosed cancer from academic and community oncology practices. JAMA Oncol. 2019;5(4):497-505. PMID: 30653226. Available from: 10.1001/jamaoncol.2018.6437.

51. El-Serag HB. Epidemiology of viral hepatitis and hepatocellular carcinoma. Gastroenterology. 2012;142(6):1264-1273.e1.
PMID: 22537432. Available from: 10.1053/j.gastro.2011.12. 061.

52. Ralphs S, Khan SA. The role of the hepatitis viruses in cholangiocarcinoma. J Viral Hepat. 2013;20(5):297-305. PMID: 23565610. Available from: $10.1111 /$ jvh.12093.

53. Lavanchy D. Hepatitis B virus epidemiology, disease burden, treatment, and current and emerging prevention and control measures. J Viral Hepat. 2004;11(2):97-107. PMID 14996343. Available from: 10.1046/j.1365-2893.2003.00487. $\mathrm{x}$.

54. de Martel C, Maucort-Boulch D, Plummer M, Franceschi S World-wide relative contribution of hepatitis $B$ and $C$ viruses in hepatocellular carcinoma. Hepatology. 2015;62(4):1190 200. PMID: 26146815. Available from: 10.1002/hep.27969.

55. Heim MH, Thimme R. Innate and adaptive immune responses in HCV infections. J Hepatol. 2014;61(1):14-25. PMID: 25443342. Available from: 10.1016/j.jhep.2014.06.035.

56. Westbrook RH, Dusheiko G. Natural history of hepatitis C. J Hepatol. 2014;61(1):58-68. PMID: 25443346. Available from: 10.1016/j.jhep.2014.07.012.

57. Vescovo T, Refolo G, Vitagliano G, Fimia GM, Piacentini M Molecular mechanisms of hepatitis $C$ virus-induced hepatocellular carcinoma. Clin Microbiol Infect. 2016;22(10):85361. PMID: 27476823. Available from: 10.1016/j.cmi.2016.07. 019.

58. Sung WK, Zheng H, Li S, Chen R, Liu X, Li Y. Genome-wide survey of recurrent HBV integration in hepatocellular carcinoma. Nat Genet. 2012;44(7):765-9. PMID: 22634754. Available from: $10.1038 / \mathrm{ng} .2295$.

59. Hayes CN, Zhang P, Zhang Y, Chayama K. Molecular mechanisms of hepatocarcinogenesis following sustained virological response in patients with chronic hepatitis $C$ virus infection. Viruses. 2018;10(10):531. PMID: 30274202. Available from: 10.3390/v10100531.

60. Young LS, Yap LF, Murray PG. Epstein-Barr virus: more than 50 years old and still providing surprises. Nat Rev Cancer. 2016;16(12):789-802. PMID: 27687982. Available from: 10. $1038 /$ nrc. 2016.92.

61. Murray PG, Young LS. An etiological role for the Epstein-Barr virus in the pathogenesis of classical Hodgkin lymphoma. Blood. 2019;134(7):591-6. PMID: 31186275. Available from: 10.1182/blood.2019000568.

62. Crombie JL, LaCasce AS. Epstein Barr virus associated Bcell lymphomas and iatrogenic lymphoproliferative disorders. Front Oncol. 2019;9:109. PMID: 30899698. Available from: 10.3389/fonc.2019.00109.

63. Aida N, Ito T, Maruyama M, Saigo K, Akutsu N, Aoyama H. A Case of Epstein-Barr Virus-Associated Leiomyosarcoma Concurrently With Posttransplant Lymphoproliferative Disorders After Renal Transplantation. Clin Med Insights Case Rep. 2019;12:1179547619867330. PMID: 31391783. Available from: $10.1177 / 1179547619867330$.

64. Ru Y, Chen J, Wu D. Epstein-Barr virus post-transplant lymphoproliferative disease (PTLD) after hematopoietic stem cell transplantation. Eur J Haematol. 2018;101(3):283-90. PMID: 29949208. Available from: 10.1111/ejh.13131.

65. Chang AM, Chiosea SI, Altman A, Pagdanganan HA, Ma C Programmed death-ligand 1 expression, microsatellite instability, Epstein-Barr virus, and human papillomavirus in nasopharyngeal carcinomas of patients from the philippines. Head Neck Pathol. 2017;11(2):203-11. PMID: 27807760. Available from: 10.1007/s12105-016-0765-y.

66. Li Z, Tsai MH, Shumilov A, Baccianti F, Tsao SW, Poirey R. Epstein-Barr virus ncRNA from a nasopharyngeal carcinoma induces an inflammatory response that promotes virus production. Nat Microbiol. 2019;4(12):2475-86. PMID: 31501540. Available from: 10.1038/s41564-019-0546-y.

67. Naseem M, Barzi A, Brezden-Masley C, Puccini A, Berger $M D$, Tokunaga R. Outlooks on Epstein-Barr virus associated gastric cancer. Cancer Treat Rev. 2018;66:15-22. PMID: 29631196. Available from: 10.1016/j.ctrv.2018.03.006. 
68. Tota JE, Engels EA, Madeleine MM, Clarke CA, Lynch CF, Ortiz AP. Risk of oral tongue cancer among immunocompromised transplant recipients and human immunodeficiency virus-infected individuals in the United States. Cancer. 2018;124(12):2515-22. PMID: 29645080. Available from: $10.1002 /$ cncr.31359.

69. Patel P, Hanson DL, Sullivan PS, Novak RM, Moorman AC Tong TC, et al. Incidence of types of cancer among HIV-infected persons compared with the general population in the United States, 1992-2003. Ann Intern Med. 2008;148(10):728-36. PMID: 18490686. Available from: 10.7326/0003-4819-148-10-200805200-00005.

70. Chinula L, Moses A, Gopal S. HIV-associated malignancies in sub-Saharan Africa: progress, challenges, and opportunities. Curr Opin HIV AIDS. 2017;12(1):89-95. PMID: 27607593. Available from: $10.1097 / \mathrm{COH} .0000000000000329$.

71. Sigel K, Makinson A, Thaler J. Lung cancer in persons with HIV. Curr Opin HIV AIDS. 2017;12(1):31-8. PMID: 27607596. Available from: 10.1097/COH.0000000000000326.

72. Yanik EL, Kaunitz GJ, Cottrell TR, Succaria F, McMiller TL, Ascierto ML. Association of HIV status with local immune response to anal squamous cell carcinoma: implications for immunotherapy. JAMA Oncol. 2017;3(7):974-8. PMID: 28334399. Available from: 10.1001/jamaoncol.2017.0115.

73. Hayakawa Y, Kobayashi K, Sakamoto N, Matsuoka M, Nozaka T, Misumi Y. A case of esophageal cancer with human immunodeficiency virus infection that progressed rapidly after neoadjuvant chemoradiotherapy. Clin J Gastroenterol. 2020;13(1):17-21. PMID: 31352645. Available from: 10.1007/ s12328-019-01028-z.

74. Galanina N, Goodman AM, Cohen PR, Frampton GM, Kurzrock R. Successful treatment of HIV-associated Kaposi sarcoma with immune checkpoint blockade. Cancer Immunol Res. 2018;6(10):1129-35. PMID: 30194084. Available from: 10.1158/2326-6066.CIR-18-0121.

75. Anampa J, Barta SK, Haigentz M, Sparano JA. Human Immunodeficiency Virus (HIV) Infection and Cancer, in Abeloff's Clinical Oncology. 2020, Elsevier. p. 894-903. e4;.

76. Jalaeikhoo H, Soleymani M, Rajaeinejad M, Keyhani M. Prevalence of Human T-lymphotropic virus type 1 (HTLV-1) Infection in Patients with Hematologic Disorders and NonHematologic Malignancies in a Tertiary Referral Hospital. Archives of Iranian medicine. 2017;20(4):0-0.

77. Sharma VK, Raimondi V, Ruggero K, Pise-Masison CA, Cavallari I, Silic-Benussi M. Expression of miR-34a in T-cells infected by human T-lymphotropic virus 1 . Front Microbiol. 2018;9:832. PMID: 29780367. Available from: 10.3389/fmicb. 2018.00832.

78. Zhang LL, Wei JY, Wang L, Huang SL, Chen JL. Human T-cell lymphotropic virus type 1 and its oncogenesis. Acta Pharmacol Sin. 2017;38(8):1093-103. PMID: 28392570. Available from: 10.1038/aps.2017.17.

79. Hirata $M$, Shinden $Y$, Nagata $A$, Nomoto $Y$, Saho $H$, Nakajo A. Clinical Features of Breast Cancer Patients with Human TCell Lymphotropic Virus Type-1 Infection. Asian Pac J Cancer Prev. 2019;20(6):1909-12. PMID: 31244317. Available from: 10.31557/APJCP.2019.20.6.1909.

80. Choi J. Successful Endoscopic Resection of Residual Colonic Mucosa-Associated Lymphoid Tissue Lymphoma after Polypectomy; 2020.

81. Moss SF. The clinical evidence linking Helicobacter pylori to gastric cancer. Cell Mol Gastroenterol Hepatol. 2016;3(2):183-91. PMID: 28275685. Available from: 10.1016/ j.jcmgh.2016.12.001.

82. Koshiol J, Wozniak A, Cook P, Adaniel C, Acevedo J, Azócar $L$, et al. Salmonella enterica serovar Typhi and gallbladder cancer: a case-control study and meta-analysis. Cancer Med. 2016;5(11):3310-3235. PMID: 27726295. Available from: 10. 1002/cam4.915.

83. Cheng WT, Kantilal HK, Davamani F. The Mechanism of Bacteroides fragilis Toxin Contributes to Colon Cancer Formation. Malays J Med Sci. 2020;27(4):9-21. PMID: 32863742
Available from: $10.21315 / \mathrm{mjms} 2020.27 .4 .2$.

84. Zhu H, Shen Z, Luo H, Zhang W, Zhu X. Chlamydia trachomatis infection-associated risk of cervical cancer: a metaanalysis. Medicine (Baltimore). 2016;95(13):e3077. PMID: 27043670. Available from: 10.1097/MD.0000000000003077.

85. Maeda M, Moro H, Ushijima T. Mechanisms for the induction of gastric cancer by Helicobacter pylori infection: aberrant DNA methylation pathway. Gastric Cancer. 2017;20(1):8-15. PMID: 27718135. Available from: 10.1007/s10120-016-06500 .

86. Rokkas T, Rokka A, Portincasa P. A systematic review and meta-analysis of the role of Helicobacter pylori eradication in preventing gastric cancer. Ann Gastroenterol. 2017;30(4):414-23. PMID: 28655977. Available from: 10 . 20524/aog.2017.0144.

87. Zhang $X Y$, Zhang PY, Aboul-Soud MA. From inflammation to gastric cancer: role of Helicobacter pylori. Oncol Lett. 2017;13(2):543-8. PMID: 28356927. Available from: 10.3892/ ol.2016.5506.

88. Kakelar HM, Barzegari A, Dehghani J, Hanifian S, Saeedi N, Barar J. Pathogenicity of Helicobacter pylori in cancer development and impacts of vaccination. Gastric Cancer. 2019;22(1):23-36. PMID: 30145749. Available from: 10.1007/ s10120-018-0867-1.

89. Posselt G, Crabtree JE, Wessler S. Proteolysis in Helicobacter pylori-induced gastric cancer. Toxins (Basel). 2017;9(4):134. PMID: 28398251. Available from: 10.3390/toxins9040134.

90. Kusano C, Gotoda T, Ishikawa H, Moriyama M. The administrative project of Helicobacter pylori infection screening among junior high school students in an area of Japan with a high incidence of gastric cancer. Gastric Cancer. 2017;20(1):16-9. PMID: 28093653. Available from: 10.1007/ s10120-017-0688-7.

91. Kakiuchi T, Matsuo M, Endo H, Nakayama A, Sato K, Takamori A. A Helicobacter pylori screening and treatment program to eliminate gastric cancer among junior high school students in Saga Prefecture: a preliminary report. J Gastroenterol. 2019;54(8):699-707. PMID: 30770975. Available from: 10.1007/s00535-019-01559-9.

92. Alfarouk KO, Bashir AH, Aljarbou AN, Ramadan AM, Muddathir AK, AlHoufie ST. The possible role of Helicobacter pylori in gastric cancer and its management. Front Oncol. 2019;9:75. PMID: 30854333. Available from: 10.3389/fonc. 2019.00075.

93. Colotta F, Allavena P, Sica A, Garlanda C, Mantovani A. Cancer-related inflammation, the seventh hallmark of cancer: links to genetic instability. Carcinogenesis. 2009;30(7):1073-81. PMID: 19468060. Available from: 10 . 1093/carcin/bgp127.

94. Gatenby RA, Gillies RJ, Brown JS. Of cancer and cave fish. Nat Rev Cancer. 2011;11(4):237-8. PMID: 21548400. Available from: $10.1038 / \mathrm{nrc} 3036$.

95. Iqbal MO, Yahya EB, Andleeb S, Ahmed MM, Javaid MU, Shakeel W, et al. In vivo Assessment of Reversing CisplatinInduced Nephrotoxicity Using Jatropha mollissima crude extract and its potential cytotoxicity. Saudi J Biol Sci. 2021;p. In press. Available from: 10.1016/j.sjbs.2021.08.057.

96. Haghi F, Goli E, Mirzaei B, Zeighami H. The association between fecal enterotoxigenic $B$. fragilis with colorectal cancer. BMC Cancer. 2019;19(1):879. PMID: 31488085. Available from: 10.1186/s12885-019-6115-1.

97. Snezhkina AV, Krasnov GS, Lipatova AV, Sadritdinova AF Kardymon OL, Fedorova MS, et al. The Dysregulation of Polyamine Metabolism in Colorectal Cancer Is Associated with Overexpression of c-Myc and C/EBP $\beta$ rather than Enterotoxigenic Bacteroides fragilis Infection. Oxid Med Cell Longev. 2016;2016:2353560. Available from: 10.1155/2016/ 2353560.

98. Tsuchiya Y, Loza E, Villa-Gomez G, Trujillo CC, Baez S, Asai T. Metagenomics of microbial communities in gallbladder bile from patients with gallbladder cancer or cholelithiasis. Asian 
Pacific journal of cancer prevention. Asian Pac J Cancer Prev. 2018;19(4):961-7. PMID: 29693356.

99. Fowler CC, Chang SJ, Gao X, Geiger T, Stack G, Galán JE. Emerging insights into the biology of typhoid toxin. Curr Opin Microbiol. 2017;35:70-7. PMID: 28213043. Available from: 10.1016/j.mib.2017.01.012.

100. Domenico EGD, Cavallo I, Pontone M, Toma L, Ensoli F. Biofilm producing Salmonella typhi: chronic colonization and development of gallbladder cancer. Int J Mol Sci. 2017;18(9):1887. PMID: 28858232. Available from: 10.3390/ ijms18091887.

101. Vagholkar K, Pawanarkar A, lyengar M, Vagholkar S. Chronic Salmonella typhi carrier state: a precursor to gall bladder cancer. International Surgery Journal. 2016;3(2):464-7. Available from: 10.18203/2349-2902.isj20160734

102. Laban M, Ibrahim EA, Hassanin AS, Nasreldin MA, Mansour A, Khalaf WM. Chlamydia trachomatis infection in primary fallopian tube and high-grade serous ovarian cancers: a pilot study. Int J Womens Health. 2019;11:199-205. PMID: 30962726. Available from: 10.2147/IJWH.S188938.

103. Salim OEH, Hamid HK, Mekki SO, Suleiman SH, Ibrahim SZ Colorectal carcinoma associated with schistosomiasis: a possible causal relationship. World J Surg Oncol. 2010;8(1):68 PMID: 20704754. Available from: 10.1186/1477-7819-8-68.

104. Han IH, Kim JH, Jang KS, Ryu JS. Inflammatory mediators of prostate epithelial cells stimulated with Trichomonas vaginalis promote proliferative and invasive properties of prostate cancer cells. Prostate. 2019;79(10):1133-46. PMID: 31050003. Available from: $10.1002 /$ pros.23826.

105. Molan AL, Rasheed EH. Study the possible link between toxoplasmosis and different kinds of cancer in Iraq. American Journal of Life Science Researches. 2016;4(3):83-8. Available from: 10.21859/ajlsr-040303.

106. Berahmat R, Mahami-Oskouei M, Rezamand A, Spotin A, Aminisani N, Ghoyounchi R. Cryptosporidium infection in children with cancer undergoing chemotherapy: how important is the prevention of opportunistic parasitic infections in patients with malignancies? Parasitol Res. 2017:116(9):2507-15. PMID: 28730516. Available from: 10.1007/s00436-017-5560-5.

107. Benamrouz S, Conseil V, Creusy C, Calderon E, Dei-Cas E, Certad G. Parasites and malignancies, a review, with emphasis on digestive cancer induced by Cryptosporidium parvum (Alveolata: Apicomplexa) . Parasite. 2012;19(2):10115. PMID: 22348213. Available from: 10.1051/parasite/ 2012192101.

108. Machicado C, Marcos LA. Carcinogenesis associated with parasites other than Schistosoma, Opisthorchis and Clonorchis: A systematic review. Int J Cancer. 2016;138(12):2915-21. PMID: 26840624. Available from: $10.1002 / \mathrm{ijc} .30028$

109. Plieskatt JL, Deenonpoe R, Mulvenna JP, Krause L, Sripa B, Bethony JM. Infection with the carcinogenic liver fluke Opisthorchis viverrini modifies intestinal and biliary microbiome. FASEB J. 2013;27(11):4572-84. PMID: 23925654. Available from: 10.1096/fj.13-232751.

110. van Tong $\mathrm{H}$, Brindley PJ, Meyer CG, Velavan TP. Parasite infection, carcinogenesis and human malignancy. EBioMedicine. 2017;15:12-23. PMID: 27956028. Available from: 10.1016/j. ebiom.2016.11.034.

111. Grivennikov $\mathrm{SI}$, Greten $\mathrm{FR}$, Karin M. Immunity, inflammation, and cancer. Cell. 2010;140(6):883-99. PMID: 20303878. Available from: 10.1016/j.cell.2010.01.025.

112. Vale N, Gouveia MJ, Gärtner F. Current and Novel Therapies Against Helminthic Infections: The Potential of Antioxidants Combined with Drugs. Biomolecules. 2020;10(3):350. PMID: 32106428. Available from: 10.3390/biom10030350.

113. Saha SK, Lee SB, Won J, Choi HY, Kim K, Yang GM. Correlation between oxidative stress, nutrition, and cancer initiation. Int J Mol Sci. 2017;18(7):1544. PMID: 28714931. Available from: 10.3390/ijms18071544.
114. Patergnani S, Danese A, Bouhamida E, Aguiari G, Previati M, Pinton P. Various Aspects of Calcium Signaling in the Regulation of Apoptosis, Autophagy, Cell Proliferation, and Cancer. Int J Mol Sci. 2020;21(21):8323. PMID: 33171939. Available from: $10.3390 / \mathrm{ijms} 21218323$.

115. zyc Bielicka VS, KoL, Jaczewska S, Bielicki D, Safranow K, Bielicki P. Colorectal cancer and Cryptosporidium spp. infection. PLoS One. 2018;13(4):e0195834. PMID: 29672572. Available from: 10.1371/journal.pone.0195834.

116. Calvisi DF. Schistoma mansoni and Hepatocellular Carcinoma: is it all about c-Jun and STAT3?; 2020. Available from: 10.1002/hep.31392.

117. Hamid HK. Schistosoma japonicum-Associated Colorectal Cancer: A Review. Am J Trop Med Hyg. 2019;100(3):501-5. PMID: 30560774 . Available from: 10.4269/ajtmh.18-0807.

118. Dematei A, Fernandes R, Soares R, Alves H, Richter J, Botelho MC. Angiogenesis in Schistosoma haematobium-associated urinary bladder cancer. APMIS. 2017;125(12):1056-62. PMID: 28960560. Available from: 10.1111/apm.12756.

119. Mohamed AM, Ahmed MA, Ahmed SA, Al-Semany SA, Alghamdi SS, Zaglool DA. Predominance and association risk of Blastocystis hominis subtype I in colorectal cancer: a case control study. Infect Agent Cancer. 2017;12(1):21. PMID: 28413436. Available from: 10.1186/s13027-017-0131-z.

120. Imam A, Al-Anzi FG, Al-Ghasham MA, Al-Suraikh MA, AlYahya AO, Rasheed Z. Serologic evidence of Toxoplasma gondii infection among cancer patients. A prospective study from Qassim region, Saudi Arabia. Saudi Med J. 2017;38(3):319-21. PMID: 28251231. Available from: 10. 15537/smj.2017.3.18535.

121. Schwartz DA. Helminths in the induction of cancer: opisthorchis viverrini, Clonorchis sinensis and cholangiocarcinoma. Trop Geogr Med. 1980;32(2):95-100. PMID: 6252671.

122. Zhu Z, Davidson KT, Brittingham A, Wakefield MR, Bai Q, Xiao $\mathrm{H}$. Trichomonas vaginalis: a possible foe to prostate cancer. Med Oncol. 2016;33(10):115. PMID: 27613161. Available from: 10.1007/s12032-016-0832-y.

123. Lovy A, Knowles B, Labbe R, Nolan L. Activity of edible mushrooms against the growth of human T4 leukemic cancer cells, HeLa cervical cancer cells, and Plasmodium falciparum. J Herbs Spices Med Plants. 2000;6(4):49-57. Available from: 10.1300/J044v06n04_06.

124. Sripa B, Brindley PJ, Mulvenna J, Laha T, Smout MJ, Mairiang $E$, et al. The tumorigenic liver fluke Opisthorchis viverrini multiple pathways to cancer. Trends Parasitol. 2012;28(10):395-407. PMID: 22947297. Available from: 10.1016/j.pt.2012.07.006.

125. Cacho-Díaz B. Neurocysticercosis in cancer patients. Neurociencia. 2019;20(6):262-5.

126. Dambuza IM, Brown GD. Fungi accelerate pancreatic cancer. Nature Publishing Group; 2019. Available from: 10.1038/ d41586-019-02892-y.

127. Aykut B, Pushalkar S, Chen R, Li Q, Abengozar R, Kim Jl. The fungal mycobiome promotes pancreatic oncogenesis via activation of MBL. Nature. 2019;574(7777):264-7. PMID: 31578522. Available from: 10.1038/s41586-019-1608-2.

128. Malik A, Sharma D, Malireddi RKS, Guy CS, Chang TC, Olsen $\mathrm{SR}$, et al. SYK-CARD9 Signaling Axis Promotes Gut FungiMediated Inflammasome Activation to Restrict Colitis and Colon Cancer. Immunity. 2018;49(3):515-530.e5. PMID: 30231985. Available from: 10.1016/j.immuni.2018.08.024.

129. Krüger W, Vielreicher S, Kapitan M, Jacobsen ID, Niemiec MJ. Fungal-bacterial interactions in health and disease. Pathogens. 2019;8(2):70. PMID: 31117285. Available from: 10.3390/pathogens8020070.

130. Tragiannidis A, Bisping G, Koehler G, Groll AH. Minireview: malassezia infections in immunocompromised patients. Mycoses. 2010;53(3):187-95. PMID: 20028460. Available from: 10.1111/j.1439-0507.2009.01814.x.

131. Guého E, Boekhout T, Ashbee HR, Guillot J, Belkum AV Faergemann J. The role of Malassezia species in the 
ecology of human skin and as pathogens. Med Mycol. 1998;36(1):220-9. PMID: 9988511.

132. Abogmaza AF, Keer KF, Takrizzah AA, Yahya EB. A Review on the Medicinal and Aromatic Plants Growing in Libya and Their Therapeutic Properties. International Research Journal of Science and Technology. 2020;2(1):327-334. Available from: 10.46378/irjst.2020.020105.

133. Iqbal MO, Yahya EB. In vivo assessment of reversing aminoglycoside antibiotics nephrotoxicity using Jatropha mollissima crude extract. Tissue Cell. 2021;72:101525. PMID: 33780659. Available from: 10.1016/j.tice.2021.101525.

134. Daley D, Mani VR, Mohan N, Akkad N, Ochi A, Heindel DW. Dectin 1 activation on macrophages by galectin 9 promotes pancreatic carcinoma and peritumoral immune tolerance. Nat Med. 2017;23(5):556-67. PMID: 28394331. Available from: $10.1038 / \mathrm{nm} .4314$.

135. Moore SC, Lee IM, Weiderpass E, Campbell PT, Sampson JN, Kitahara CM. Association of leisure-time physical activity with risk of 26 types of cancer in 1.44 million adults. JAMA Intern Med. 2016;176(6):816-25. PMID: 27183032. Available from: 10.1001/jamainternmed.2016.1548.

136. Holmes MD, Chen WY, Feskanich D, Kroenke CH, Colditz GA. Physical activity and survival after breast cancer diagnosis. JAMA. 2005;293(20):2479-86. PMID: 15914748. Available from: 10.1001/jama.293.20.2479.

137. Kenfield SA, Stampfer MJ, Giovannucci E, Chan JM. Physical activity and survival after prostate cancer diagnosis in the health professionals follow-up study. J Clin Oncol. 2011;29(6):726-32. PMID: 21205749. Available from: 10. 1200/JCO.2010.31.5226.

138. Gabriel BM, Zierath JR. The limits of exercise physiology: from performance to health. Cell Metab. 2017;25(5):100011. PMID: 28467920 . Available from: 10.1016/j.cmet.2017.04 018.

139. Yahya EB, Alzalouk MM, Alfallous KA, Abogmaza AF. Antibacterial cellulose-based aerogels for wound healing application: A review. Biomed Res Ther. 2020;7(10):4032-40. Available from: 10.15419/bmrat.v7i10.637.

140. Allaq AA, Sidik NJ, Abdul-Aziz A, Ahmed IA. Cumin (Cuminum cyminum L.): A review of its ethnopharmacology, phytochemistry. Biomed Res Ther. 2020;7(9):4016-21. Available from: 10.15419/bmrat.v7i9.634.

141. Yahya EB, Amirul AA, S AKHP, Olaiya NG, lqbal MO, Jummaat F. Insights into the Role of Biopolymer Aerogel Scaffolds in Tissue Engineering and Regenerative Medicine. Polymers (Basel). 2021;13(10):1612. PMID: 34067569. Available from: $10.3390 /$ polym13101612.

142. Yahya EB, Jummaat $F$, Amirul AA, Adnan AS, Olaiya NG, Abdullah CK. A review on revolutionary natural biopolymerbased aerogels for antibacterial delivery. Antibiotics (Basel).
2020;9(10):648. PMID: 32998197. Available from: 10.3390/ antibiotics9100648.

143. Kich DM, Vincenzi A, Majolo F, de Souza CFV, Goettert MI. Probiotic: effectiveness nutrition in cancer treatment and prevention. Nutr Hosp. 2016;33(6):1430-7. PMID: 28000477. Available from: 10.20960/nh.806.

144. Jacouton $\mathrm{E}$, Chain $\mathrm{F}$, Sokol H, Langella $\mathrm{P}$, Bermúdez-Humarán LG. Probiotic strain Lactobacillus casei BL23 prevents colitisassociated colorectal cancer. Front Immunol. 2017;8:1553. PMID: 29209314. Available from: 10.3389/fimmu.2017.01553.

145. Shin DS, Rhee KJ, Eom YB. Effect of probiotic Clostridium butyricum NCTC 7423 supernatant on biofilm formation and gene expression of Bacteroides fragilis. J Microbiol Biotechnol. 2020;30(3):368-77. PMID: 32066216. Available from: 10.4014/jmb.2001.01027.

146. Abdelhamid AG, Esaam A, Hazaa MM. Cell free preparations of probiotics exerted antibacterial and antibiofilm activities against multidrug resistant E. coli. Saudi Pharm J. 2018;26(5):603-7. PMID: 29991904. Available from: 10.1016/ j.jsps.2018.03.004.

147. Almashgab AM, Yahya EB, Banu A. The Cytotoxicity Effects of Outer Membrane Vesicles Isolated from Hospital and Laboratory Strains of Pseudomonas Aeruginosa on Human Keratinocyte Cell Line. Malays J Sci. 2020;39(3):45-53. Available from: 10.22452/mjs.vol39no3.3.

148. Rizal S, Lai TK, Muksin U, Olaiya NG, Abdullah CK, Ikramullah. Properties of Macroalgae Biopolymer Films Reinforcement with Polysaccharide Microfibre. Polymers (Basel). 2020;12(11):2554. PMID: 33143383. Available from: 10.3390/ polym12112554.

149. Barzegari A, Kheyrolahzadeh K, Khatibi SMH, Sharifi S, Mema MY, Vahed SZ. The battle of probiotics and their derivatives against biofilms. Infect Drug Resist. 2020;13:659-72. PMID: 32161474. Available from: 10.2147/IDR.S232982.

150. Khalil HPA, Adnan AS, Yahya EB, Olaiya NG, Safrida S, Hossain MS. A Review on plant cellulose nanofibre-based aerogels for biomedical applications. Polymers (Basel). 2020;12(8):1759. PMID: 32781602. Available from: 10.3390/ polym12081759.

151. Bishayee A, Sethi G. Bioactive natural products in cancer prevention and therapy: Progress and promise. in Seminars in cancer biology. 2016. Elsevier. 10.1016/j.semcancer.2016.08.006. Elsevier.

152. Song M, Vogelstein B, Giovannucci EL, Willett WC, Tomasetti C. Cancer prevention: molecular and epidemiologic consensus. Science. 2018;361(6409):1317-8. PMID: 30262488. Available from: $10.1126 /$ science.aau 3830 .

153. Chew SS, Tan LT, Law JW, Pusparajah P, Goh BH, Mutalib NSA. Targeting Gut Microbial Biofilms-A Key to Hinder Colon Carcinogenesis? Cancers (Basel). 2020;12(8):2272. PMID: 32823729. Available from: 10.3390 /cancers 12082272 . 
Ready to submit your manuscript? Choose Biomedpress and benefit from:

- Fast, convenient online submission

- Through peer-review by experienced researchers

- Rapid publication on acceptance

- Free of charge (without publication fees)

Learn more http://www.biomedpress.org/journals/

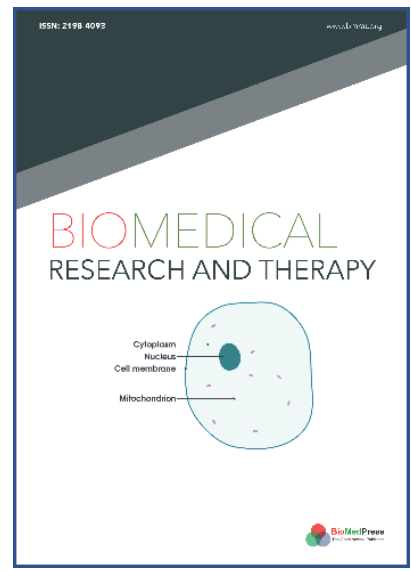

\title{
Biomedical Research and Therapy
}

Indexed: Web of Science (ESCl), Embase, Google Scholar

Journal Citation Indicator (2020): 0.16

Acceptance Rate (2020): 54.32\%

Article Publishing Charge: Free

Submission to first editorial decision: 27 days

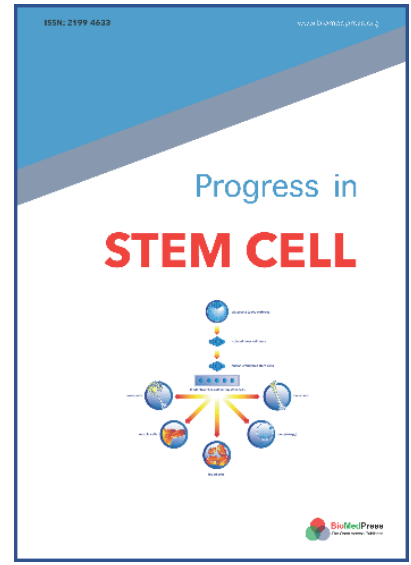

\section{Progress in Stem Cell}

Indexed: Embase, Google Scholar

Acceptance Rate (2020): 78.19\%

Article Publishing Charge: Free

Submission to first editorial decision: 19 days

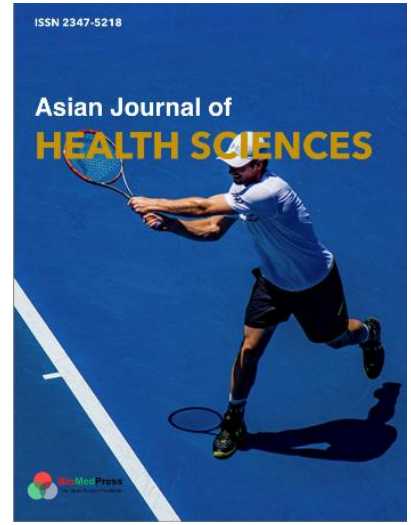

\author{
Asian Journal of Health Sciences \\ Indexed: Google Scholar \\ Acceptance Rate (2020): 72.89\% \\ Article Publishing Charge: Free \\ Submission to first editorial decision: 16.5 days
}

